\title{
A Role for Hypocretin/Orexin Receptor-I in Cue-Induced Reinstatement of Nicotine-Seeking Behavior
}

\author{
Ainhoa Plaza-Zabala', África Flores', Elena Martín-García', Rocío Saravia', Rafael Maldonado' and \\ Fernando Berrendero*,
}

'Laboratory of Neuropharmacology, Department of Experimental and Health Sciences, Universitat Pompeu Fabra, Barcelona, Spain

\begin{abstract}
Hypocretin/orexin signaling is critically involved in relapse to drug-seeking behaviors. In this study, we investigated the involvement of the hypocretin system in the reinstatement of nicotine-seeking behavior induced by nicotine-associated cues. Pretreatment with the hypocretin receptor-I antagonist SB334867, but not with the hypocretin receptor-2 antagonist TCSOX229, attenuated cue-induced reinstatement of nicotine-seeking, which was associated with an activation of hypocretin neurons of the lateral and perifornical hypothalamic areas. In addition, relapse to nicotine-seeking increased the phosphorylation levels of GluR2-Ser880, NRI-Ser890, and p38 MAPK in the nucleus accumbens (NAc), but not in the prefrontal cortex. Notably, phosphorylation levels of NRI-Ser890 and p38 MAPK, but not GluR2-Ser880, were dependent on hypocretin receptor-I activation. The intra-accumbens infusion of the protein kinase $C$ (PKC) inhibitor NPC-15437 reduced nicotine-seeking behavior elicited by drug-paired cues consistent with the PKC-dependent phosphorylations of GluR2-Ser880 and NRI-Ser890. SB334867 failed to modify cue-induced reinstatement of food-seeking, which did not produce any biochemical changes in the NAc. These data identify hypocretin receptor-I and PKC signaling as potential targets for the treatment of relapse to nicotine-seeking induced by nicotine-associated cues.

Neuropsychopharmacology (2013) 38, 1724-1736; doi:I0.1038/npp.2013.72; published online 17 April 20I3
\end{abstract}

Keywords: nicotine; hypocretin; cue; reinstatement; glutamate; PKC

\section{INTRODUCTION}

Tobacco use is the leading cause of preventable death in developed countries. However, despite the harmful health consequences of tobacco smoking, approximately $80 \%$ of smokers attempting to quit on their own relapse within the first month of abstinence and only around $3 \%$ remain abstinent at 6 months (Benowitz, 2009). A critical factor responsible for these high rates of relapse is the re-exposure to environmental stimuli associated with nicotine consumption (Caggiula et al, 2001; Chiamulera, 2005).

Several neurotransmitters are involved in the addictive properties of nicotine, which is considered the main psychoactive constituent of tobacco (Berrendero et al, 2010; De Biasi and Dani, 2011). Hypocretin-1 and -2 (also known as orexin A and B) are lateral hypothalamic neuropeptides that project throughout the brain (Peyron et al, 1998) and have an important role in drug addiction (Aston-Jones et al, 2010; Plaza-Zabala et al, 2012a). Increasing evidence suggests that hypocretin transmission is involved in nicotine-addictive effects. Thus, the hypocre-

*Correspondence: Dr F Berrendero, Laboratory of Neuropharmacology, Department of Experimental and Health Sciences, University Pompeu Fabra, PRBB, C/Doctor Aiguader 88, Barcelona 08003, Spain, Tel: +3493 3160890, Fax: +3493 3160901,

E-mail: fernando.berrendero@upf.edu

Received I November 2012; revised 4 March 2013; accepted 18 March 2013; accepted article preview online 21 March 2013 tin receptor-1 (Hcrtr-1) antagonist SB334867 (Hollander et al, 2008) and the mixed Hcrtr-1/Hcrtr-2 antagonist almorexant (LeSage et al, 2010) decreased nicotine selfadministration in rats. Hcrtr-1 signaling in the hypothalamic paraventricular nucleus was shown to participate in the somatic signs of nicotine withdrawal (Plaza-Zabala et al, 2012b). In addition, hypocretin-1 induced reinstatement of previously extinguished nicotine-seeking behavior in mice by a mechanism independent of the corticotrophin-releasing factor (CRF) (Plaza-Zabala et al, 2010). In spite of these findings, the potential participation of hypocretin transmission in the reinstatement of nicotine-seeking induced by nicotine-associated cues, one of the most relevant clinical factors, remains largely unexplored.

In this study, we investigated the specific contribution of Hcrtr-1 and Hcrtr-2 in cue-induced reinstatement of nicotine-seeking behavior. Relapse to drug-seeking behavior is associated with changes in synaptic plasticity involving excitatory glutamatergic transmission (Knackstedt and Kalivas, 2009) and MAPK signaling pathway (Wang et al, 2007). Therefore, we investigated the effects of cue-induced reinstatement of nicotine-seeking and the influence of hypocretin transmission in the phosphorylation of NMDA and AMPA glutamate receptor subunits as well as MAPK pathway activity in the nucleus accumbens (NAc) and the prefrontal cortex (PFC). To test the selectivity of these changes for nicotine reinstatement, we studied the influence of hypocretin signaling on the 
behavioral and biochemical effects produced by the reinstatement of cue-induced food-seeking.

\section{MATERIALS AND METHODS}

\section{Animals}

Experiments were performed using male C57BL/6 J mice (8-10-week old) (Charles River) single-housed in a temperature $\left(21.1 \pm 1{ }^{\circ} \mathrm{C}\right)$ - and humidity $(55 \pm 10 \%)$-controlled room under reversed light/dark cycle conditions (lights off at 0800 hours). Mice were habituated to reversed cycle and handled during 1 week before starting with the operant training sessions. The experiments took place during the dark phase. Food and water were available ad libitum except for mice that were tested for food-seeking behavior. The observer was blind to treatment in all the experiments. Animal procedures were conducted in accordance with the guidelines of the European Communities Directive 86/609/ EEC regulating animal research, the local ethical committee (CEEA-IMAS-UPF), and the statement of compliance with standards for use of laboratory animals by foreign institutions no. A5388-01 approved by the National Institutes of Health (USA).

\section{Drugs}

(-)-Nicotine hydrogen tartrate salt ((-)-1-methyl-2(3-pyridyl)pyrrolidine; Sigma) was dissolved in physiological saline $(0.9 \% \mathrm{NaCl})$. The $\mathrm{pH}$ of the nicotine solution was adjusted to 7.4 and was contingently administered by intravenous (iv) route at the dose of $30 \mu \mathrm{g} / \mathrm{kg}$ per infusion (free base). The Hcrtr-1 antagonist SB334867 (Tocris Bioscience) was dissolved in 1\% (2-hydroxypropyl)- $\beta$ cyclodextrin (Sigma) and 10\% DMSO in distilled water. The Hcrtr-2 antagonist TCSOX229 (Tocris Bioscience) was dissolved in physiological saline. SB334867 and TCSOX229 were administered by intraperitoneal (ip) route in a volume of $5 \mathrm{ml} / \mathrm{kg}$ ( 5 and $10 \mathrm{mg} / \mathrm{kg}$ ). The protein kinase C (PKC) inhibitor NPC-15437 dihydrochloride hydrate (Sigma) was dissolved in physiological saline and administered by ip route in a volume of $10 \mathrm{ml} / \mathrm{kg}(0.5$ and $1 \mathrm{mg} / \mathrm{kg})$ or by intraaccumbal route $(1 \mu \mathrm{g} / 0.5 \mu \mathrm{l} /$ side $)$. Ketamine hydrochloride $(100 \mathrm{mg} / \mathrm{kg}$; Imalgène 1000) and xylazine hydrochloride ( $20 \mathrm{mg} / \mathrm{kg}$; Sigma) were mixed and dissolved in ethanol $(5 \%)$ and distilled water $(95 \%)$. This anesthetic mixture was administered ip in a volume of $10 \mathrm{ml} / \mathrm{kg}$ body weight. Thiopental sodium ( $5 \mathrm{mg} / \mathrm{ml}$; Braun Medical S.A.) was dissolved in distilled water and delivered in a volume of $0.05 \mathrm{ml}$ through the iv catheter.

\section{Cue-Induced Reinstatement of Nicotine-Seeking Behavior}

Jugular vein catheterization. Mice were anesthetized with a ketamine/xylazine mixture and then implanted with indwelling iv silastic catheters in their right jugular vein as previously described (Soria et al, 2005). Briefly, silastic tubing of $6 \mathrm{~cm}$ long $(0.3 \mathrm{~mm}$ inner diameter, $0.6 \mathrm{~mm}$ outer diameter; Silastic, Dow Corning) was fitted to a 22-gauge steel cannula (Semat) that was bent at a right angle and then embedded in a cement disk (Dentalon Plus, Eraeus) with an underlying nylon mesh. The catheter tubing was inserted $1.3 \mathrm{~cm}$ into the right jugular vein and anchored with suture. The remaining tubing ran subcutaneously to the cannula, which exited at the midscapular region. All incisions were sutured and coated with antibiotic ointment (Bactroban, GlaxoSmithKline). After surgery, mice were allowed to recover for 4 days before initiation of self-administration sessions.

Apparatus. The experiments were conducted in mouse operant chambers (model ENV-307A-CT; Med Associates Inc.) equipped with two holes, one randomly selected as the active hole and the other as the inactive hole. Pump noise and stimuli lights (environmental cues), one located inside the active hole and the other above it were paired with the delivery of the reinforcer. Nicotine $(30 \mu \mathrm{g} / \mathrm{kg} /$ infusion, free base) was delivered in a volume of $23.5 \mu \mathrm{l}$ over $2 \mathrm{~s}$ via a syringe that was mounted on a microinfusion pump and connected via Tygon tubing to a single channel liquid swivel and to the mouse iv catheter.

Self-administration training. Slight modifications were applied to the previously described operant model (MartínGarcía et al, 2009). One hour daily self-administration sessions were conducted consecutively for 10 days. Mice were trained under a fixed ratio 1 schedule of reinforcement with a 10-s time-out. Each daily session started with a priming injection of the drug. The stimuli light together with the pump noise (environmental cues) signaled delivery of nicotine infusion through the entire self-administration session. During the 10-s time-out period, the cue light was off and no reward was provided after active nose-poking. Responses on the inactive hole and all the responses elicited during the time-out period were also recorded. The session was terminated after 50 reinforcers were delivered or after $1 \mathrm{~h}$, whichever occurred first. The criteria for the acquisition of self-administration behavior were achieved when in three consecutive sessions: (1) mice maintained a stable responding with $<20 \%$ deviation from the mean of the total number of reinforcers earned ( $80 \%$ stability); (2) at least $75 \%$ responding on the active hole, and (3) a minimum of 6 reinforcers per session. The patency of iv catheters was evaluated at the end of nicotine self-administration training by an infusion of $0.05 \mathrm{ml}$ of thiopental sodium through the catheter. If prominent signs of anesthesia were not apparent within $3 \mathrm{~s}$ of the infusion, the mouse was removed from the experiment. Only mice with patent catheter that met all the acquisition criteria were moved to the extinction phase.

Extinction. During the extinction period, nicotine and environmental cues were not available after active nosepoking. Mice were given $1 \mathrm{~h}$ daily sessions 6 days per week until reaching the extinction criterion during a maximum of 50 days. The criterion was achieved when active responses were $<30 \%$ of the mean responses obtained during the 3 days achieving the acquisition criteria across 3 consecutive extinction sessions. Only mice that reached the extinction criterion were evaluated for reinstatement. 
Cue-induced reinstatement of nicotine-seeking behavior. One day after reaching the extinction criterion, mice were tested in a single cue-induced reinstatement session that lasted for $1 \mathrm{~h}$. At the beginning of the session, mice were re-exposed to the pump noise and stimuli lights (environmental cues) for $2 \mathrm{~s}$. Subsequently, each active nose-poke led to the presentation of the same environmental cues. Nicotine was not available through the entire session. To evaluate the involvement of Hcrtr-1, Hcrtr-2, and PKC in this behavioral response, different groups of mice were pretreated with the Hcrtr-1 antagonist SB334867 (5 and $10 \mathrm{mg} / \mathrm{kg}$, ip), the Hcrtr-2 antagonist TCSOX229 (5 and $10 \mathrm{mg} / \mathrm{kg}$, ip), the PKC inhibitor NPC-15437 (0.5 and $1 \mathrm{mg} / \mathrm{kg}$, ip or $1 \mu \mathrm{g} / 0.5 \mu \mathrm{l} / \mathrm{side}$, intra-NAc), or vehicle $30 \mathrm{~min}$ before the initiation of the cue-induced reinstatement test. These doses were selected based on previous experiments (Aujla and Beninger, 2003; Sato et al, 2004; Lai et al, 2008; Plaza-Zabala et al, 2010, 2012b) and do not affect locomotor activity (Lai et al, 2008; Plaza-Zabala et al, 2010; Figure 4; Supplementary Figure S1).

Cannula implantation and intra-NAc infusion of NPC15437. One day after the end of nicotine self-administration training, a group of mice were implanted with bilateral intra-craneal cannulae to assess the role of accumbal PKC on cue-induced reinstatement of nicotine-seeking. Mice were anesthetized with a ketamine/xylazine mixture and placed in a stereotaxic frame (KOPF Instruments, Tujunga, CA). Bilateral guide cannulae (26 gauge, $8 \mathrm{~mm}$ long) were implanted at the following coordinates relative to bregma and the skull surface: anteroposterior, $+1.35 \mathrm{~mm}$; mediolateral, $\pm 1 \mathrm{~mm}$; dorsoventral, $-3.6 \mathrm{~mm}$; flat skull position (Paxinos and Franklin, 1997). The cannulae were fixed to the skull with dental cement. Mice were allowed for 2 days of postoperative recovery before beginning with extinction training. One day after reaching the extinction criterion, NPC-15437 $(1 \mu \mathrm{g} / 0.5 \mu \mathrm{l} / \mathrm{side})$ or vehicle was microinjected bilaterally into the NAc $30 \mathrm{~min}$ before the cue-induced reinstatement test. Freely moving mice were prepared with injector cannulae (33 gauge, $9 \mathrm{~mm}$ long) that extended $1 \mathrm{~mm}$ from the guide cannulae to reach the NAc $(4.6 \mathrm{~mm}$ dorsoventral from skull surface). The injector cannula was connected through polyethylene tubing (PE-20, Plastics One, Roanoke, VA) to a 10- $\mu$ l Hamilton microsyringe (Hamilton, Reno, NV) that delivered NPC-15437 or vehicle at a constant rate of $0.5 \mu \mathrm{l} / \mathrm{min}$ through a multiple microsyringe-driven pump (Harvard 22, Harvard). Polyethylene tubing was removed from the injector cannulae 2 min after NPC- 15437 or vehicle infusion to prevent drug reflux.

\section{Cue-Induced Reinstatement of Food-Seeking Behavior}

Slight modifications were performed to a recently described food-seeking model (Martín-García et al, 2011). See Supplementary Materials and Methods for further details.

\section{Locomotor Activity}

The locomotor responses induced by the ip administration $(0.5$ and $1 \mathrm{mg} / \mathrm{kg})$ or intra-NAc infusion $(1 \mu \mathrm{g} / 0.5 \mu \mathrm{l} /$ side $)$ of NPC-15437 were measured by using individual locomotor activity boxes $\left(9 \times 20 \times 11 \mathrm{~cm}^{3}\right.$, Imetronic, Pessac, France). See Supplementary Materials and Methods for further details.

\section{Immunofluorescence}

See Supplementary Materials and Methods for details.

\section{Immunoblot Analysis}

See Supplementary Materials and Methods for details.

\section{Data Analysis}

Two-way ANOVA with repeated measures was used to analyze the acquisition of nicotine self-administration and food-maintained operant behaviors (hole and day as within-subject factors). The analysis was followed by Fisher's LSD test for each day of training. One-way ANOVA with repeated measures (with experimental phase as within-subject factor) was applied to evaluate the reinstatement elicited by presentation of nicotine- or food-associated cues in mice extinguished from operant behavior. The effects of the pretreatment with SB334867, TCSOX229, or NPC-15437 on cue-induced reinstatement of nicotineand food-seeking behavior were compared using one-way ANOVA followed by post-hoc analyses (Newman-Keuls) when required. The results of immunofluorescence and immunoblot experiments were analyzed by Student's $t$-test. The level of significance was $P<0.05$ in all the experiments.

\section{RESULTS}

\section{Acquisition and Extinction of Nicotine Self- Administration behaviors}

Mice were trained to self-administer nicotine $(30 \mu \mathrm{g} / \mathrm{kg}$ per infusion, free base) during 10 consecutive days. Two-way ANOVA with repeated measures revealed an interaction between day of training and hole $\left(\mathrm{F}_{(9,540)}=18.40, P<0.01\right)$, indicating a progressive acquisition of the operant behavior across days (Figure 1a). The acquisition criteria were achieved in $8 \pm 0.2$ days by $71 \%$ of mice trained to selfadminister nicotine. We have previously shown using this operant paradigm that mice trained to self-administer nicotine reliably acquired the behavior when compared with mice self-administering saline (Plaza-Zabala et al, 2010; Martín-García et al, 2009). Mice that met the acquisition criteria for nicotine self-administration behavior went through extinction sessions. The extinction criterion was achieved by $89 \%$ of mice in $18 \pm 1.2$ days (Figure 1b). During the first extinction session, mice showed a significant increase in the number of responses in the active hole $(20 \pm 1.4)$ compared with the last day of nicotine self-administration training $(17 \pm 0.9) \quad(P<0.05)$ (Figure $1 \mathrm{a}$ and $\mathrm{b}$ ), indicating a reliable acquisition of nicotine self-administration behavior. One day after the mice met the extinction criterion, they were tested for cueinduced reinstatement of nicotine-seeking. 

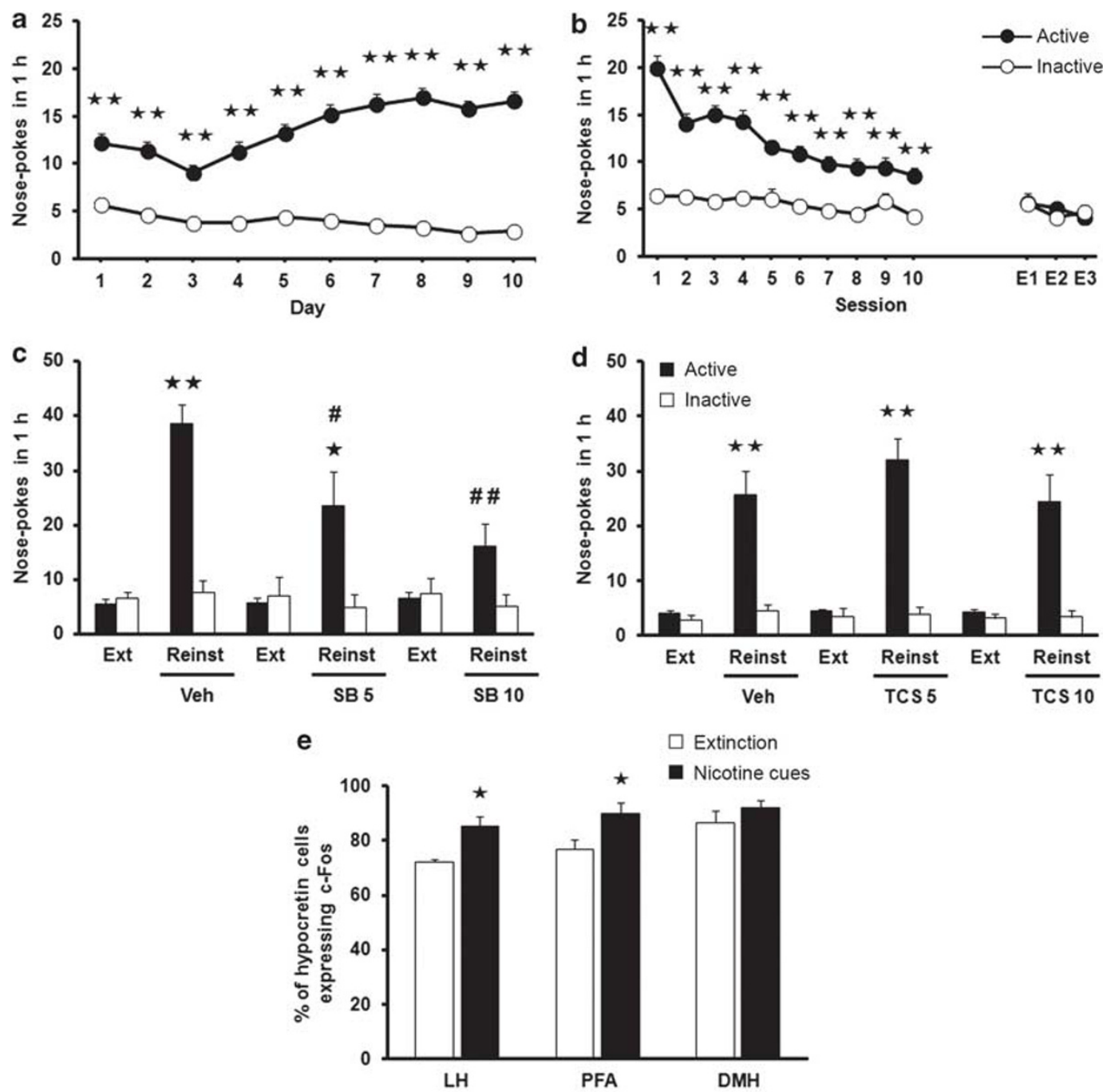

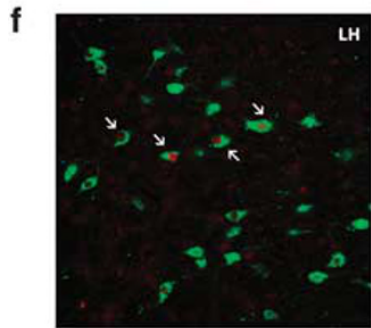

Extinction

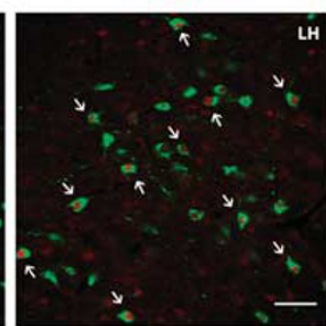

Reinstatement

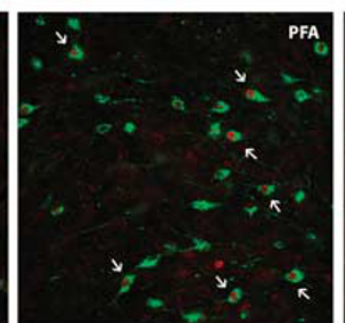

Extinction

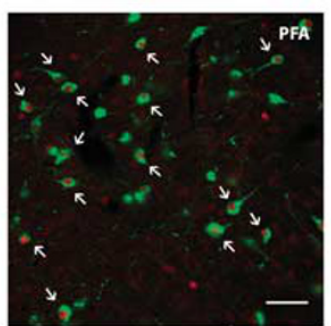

Reinstatement

Figure I Hcrtr-I selectively attenuates cue-induced reinstatement of nicotine-seeking behavior. (a-d) Mean number of nose-poking responses in the active (black) and inactive (white) hole during (a) acquisition of nicotine self-administration behavior $(n=6 \mathrm{I})$, (b) extinction training ( $n=6 \mathrm{I}$ ) (EI-E2-E3, 3 days achieving the extinction criterion), and (c, d) cue-induced reinstatement of nicotine-seeking after pretreatment with (c) SB334867 (0, 5, and 10 mg $/ \mathrm{kg}$, ip; $n=8-11$ mice per group) or (d) TCSOX229 (0, 5, and 10 mg $/ \mathrm{kg}$, ip; $n=8-9$ mice per group). (e) Percentage of hypocretin cells expressing c-Fos in the lateral hypothalamus (LH), perifornical area (PFA) and dorsomedial hypothalamus (DMH) in mice extinguished from nicotine self-administration behavior or re-exposed to nicotine-associated cues ( $n=4$ mice per group). ( $f$ Representative images of sections of the LH and the PFA obtained by confocal microscopy after direct double labeling combining rabbit polyclonal antiserum to c-Fos (red) with mouse monoclonal antibody to hypocretin-I (green). Arrowheads indicate c-Fos-positive hypocretin-I-expressing neurons. Bar $=50 \mu \mathrm{m}$. Data are expressed as mean $\pm S E M$. (a, b) $* * P<0.01$ comparison between holes, $(c-e){ }^{*} P<0.05$, ${ }^{*} * P<0.0$ I compared with extinction, ${ }^{\#} P<0.05$, ${ }^{\# \#} P<0.0$ I compared with vehicle pretreatment.

Pretreatment With SB334867, but not TCSOX229, Attenuated Cue-Induced Reinstatement of Nicotine-Seeking Behavior

Reinstatement studies were performed using a betweensubjects design. Thus, different groups of mice were tested for cue-induced reinstatement after pretreatment with vehicle, the Hcrtr-1 antagonist SB334867 (5 and $10 \mathrm{mg} / \mathrm{kg}$, ip), or the Hcrtr-2 antagonist TCSOX229 (5 and $10 \mathrm{mg} / \mathrm{kg}$, ip). To exclude any possible bias of nicotine-acquisition levels, two-way ANOVA with repeated measures was performed among the different groups of treatment tested 
for reinstatement. As expected, two-way ANOVA revealed a significant effect of day of training $\left(\mathrm{F}_{(9,423)}=11.89\right.$, $P<0.01$ ), but no significant effect of the treatment groups tested for reinstatement $\left(\mathrm{F}_{(5,47)}=0.19, \mathrm{NS}\right)$ or interaction between the two factors $\left(\mathrm{F}_{(45,423)}=1.06, \mathrm{NS}\right)$, indicating the absence of differences on self-administration levels for the different groups tested for reinstatement.

As previously reported (Martín-García et al, 2009), mice presented with nicotine-associated cues reinstated a previously extinguished nicotine-seeking behavior (Figure 1c and d). Pretreatment with the Hcrtr-1 antagonist SB334867 dose-dependently attenuated this effect (Figure 1c). Oneway ANOVA revealed a significant effect of SB334867 treatment on reinstatement $\left(\mathrm{F}_{(2,27)}=7.13, P<0.01\right)$. Subsequent post-hoc analysis confirmed that mice treated with SB334867 at $5 \mathrm{mg} / \mathrm{kg}(P<0.05)$ and $10 \mathrm{mg} / \mathrm{kg} \quad(P<0.01)$ showed lower active responses than vehicle-treated mice. Conversely, pretreatment with the Hcrtr-2 antagonist TCSOX229 did not influence responding after presentation of nicotine-conditioned cues $\left(\mathrm{F}_{(2,24)}=0.84\right.$, NS; Figure $\left.1 \mathrm{~d}\right)$, indicating that Hcrtr-1 has a specific role in the modulation of this behavior.

\section{Re-exposure to Nicotine-Paired Cues Activated Hypocretin Neurons in the Lateral and Perifornical Hypothalamic Areas}

To further explore the involvement of hypocretin transmission in cue-induced reinstatement of nicotine-seeking, we evaluated the possible activation of hypocretin neurons by using double-labeled immunofluorescence of c-Fos with hypocretin-1 in the lateral hypothalamic area. The percentage of c-Fos-positive hypocretin neurons increased in the lateral hypothalamus ( $\mathrm{LH} ; P<0.05)$ and the perifornical area (PFA; $P<0.05)$ after presentation of nicotine-associated cues (Figure 1e and f). By contrast, c-Fos expression in hypocretin cells from the dorsomedial hypothalamus $(\mathrm{DMH})$ remained unchanged (Figure 1e), indicating that LH and PFA subpopulations of hypocretin neurons are specifically engaged during cue-elicited reinstatement of nicotine-seeking behavior.

\section{Cue-Induced Reinstatement of Nicotine-Seeking was Associated with an Hcrtr-1-Dependent Phosphorylation of NR1-Ser890 and p38 MAPK in the NAc}

Changes on excitatory glutamatergic transmission have a crucial role in drug-seeking behaviors (Kalivas, 2009). Phosphorylation of NMDA and AMPA receptor subunits participates in the regulation of trafficking, surface expression, and function of these receptors (Santos et al, 2009; Gladding and Raymond, 2011), which modulates the efficacy and strength of excitatory synapses (Wang et al, 2006). Additionally, the MAPK signaling pathway is directly involved in the regulation of synaptic plasticity (Wang et al, 2007). Therefore, we evaluated the possible changes induced by nicotine-seeking in the phosphorylation levels of NMDA and AMPA receptor subunits, as well as some MAPK in two key regions relevant to drug relapse, NAc and PFC. Interestingly, cue-induced reinstatement of nicotine-seeking elicited an increase in the phosphorylation levels of GluR2-Ser880, NR1-Ser890, and p38 MAPK in the NAc
$(P<0.05)$ (Figure 2a, d, and $\mathrm{f})$. Other phosphorylations analyzed in the same brain region, such as GluR1-Ser831, GluR1-Ser845, NR1-Ser896, and ERK were not influenced by nicotine-seeking (Figure 2b, c, e, and g). Notably, phosphorylation levels of NR1-Ser890 and p38 MAPK $(P<0.05)$, but not GluR2-Ser880, were significantly reduced in the NAc of mice pretreated with SB334867 (10 mg/kg, ip) (Figure 2a, $\mathrm{d}$, and f). SB334867 (10 mg/kg, ip) treatment per se did not modify the phosphorylation levels of NR1-Ser890 and p38 MAPK in the NAc (Figure $2 \mathrm{~h}$ and $\mathrm{i}$ ). On the contrary, analysis of the same phosphorylations in the PFC did not reveal any differences (Figure 3 ). These results indicate that cue-induced reinstatement of nicotine-seeking increases phosphorylation of GluR2-Ser880, NR1-Ser890, and p38 MAPK in the NAc. However, only NR1-Ser890 and p38 MAPK phosphorylations depend on Hcrtr-1 activation.

\section{Intra-NAc Infusion of the PKC Inhibitor NPC-15437 Blocked Nicotine-Seeking Behavior Elicited by Drug-Paired Cues}

Both GluR2-Ser880 and NR1-Ser890 are PKC-regulated phosphorylation sites (Tingley et al, 1997; Chung et al, 2000). Moreover, cue-induced reinstatement of nicotineseeking increased phosphorylation levels of PKC target proteins in the NAc $(P<0.05)$ (Figure $4 \mathrm{a}$ and $\mathrm{b})$, as assessed by an antibody that specifically recognizes PKC phosphorylated substrates. Therefore, we next evaluated whether PKC signaling had a role in nicotine-seeking behavior promoted by nicotine-conditioned cues. A between-subjects design was used to perform this experiment. Pretreatment with the PKC inhibitor NPC-15437 (0.5 and $1 \mathrm{mg} / \mathrm{kg}$, ip) dosedependently attenuated cue-elicited reinstatement of nicotine-seeking (Figure 4d). One-way ANOVA showed a significant effect of NPC-15437 treatment during reinstatement $\left(\mathrm{F}_{(2,27)}=5.19, P<0.05\right)$, and post-hoc analysis revealed that only the high dose of the PKC inhibitor $(1 \mathrm{mg} / \mathrm{kg}$, ip) $(P<0.05)$ attenuated this behavioral response. This effect was not due to changes in locomotion as NPC-15437 (0.5 and $1 \mathrm{mg} / \mathrm{kg}$, ip) did not modify locomotor activity (Figure 4c). Furthermore, the PKC inhibitor was effective in blocking the activity of this enzyme as pretreatment with NPC-15437 attenuated the phosphorylation of PKC substrates in the NAc of mice tested for reinstatement $(P<0.05$; Figure $4 \mathrm{a}$ and $\mathrm{b})$. Based on these biochemical and behavioral data, we next assessed the specific contribution of accumbal PKC to cue-induced reinstatement of nicotineseeking behavior. The intra-NAc infusion of NPC-15437 $(1 \mu \mathrm{g} / 0.5 \mu \mathrm{l} / \mathrm{side}) \quad$ blocked this behavioral response $(P<0.01)$, whereas it did not alter locomotor activity (Figure $4 \mathrm{e}$ and $\mathrm{f}$ ), demonstrating that $\mathrm{PKC}$ signaling in the NAc is essential for reinstatement of nicotine-seeking behavior following re-exposure to nicotine-conditioned cues.

\section{Hypocretin Receptors do not Influence Cue-Induced Reinstatement of Food-Seeking Behavior}

To discard any potential non-specific effects of SB334867 and TCSOX229 on the reinstatement of nicotine-seeking behavior and the possible modifications that the operant behavior by itself could induce in the biochemical changes 

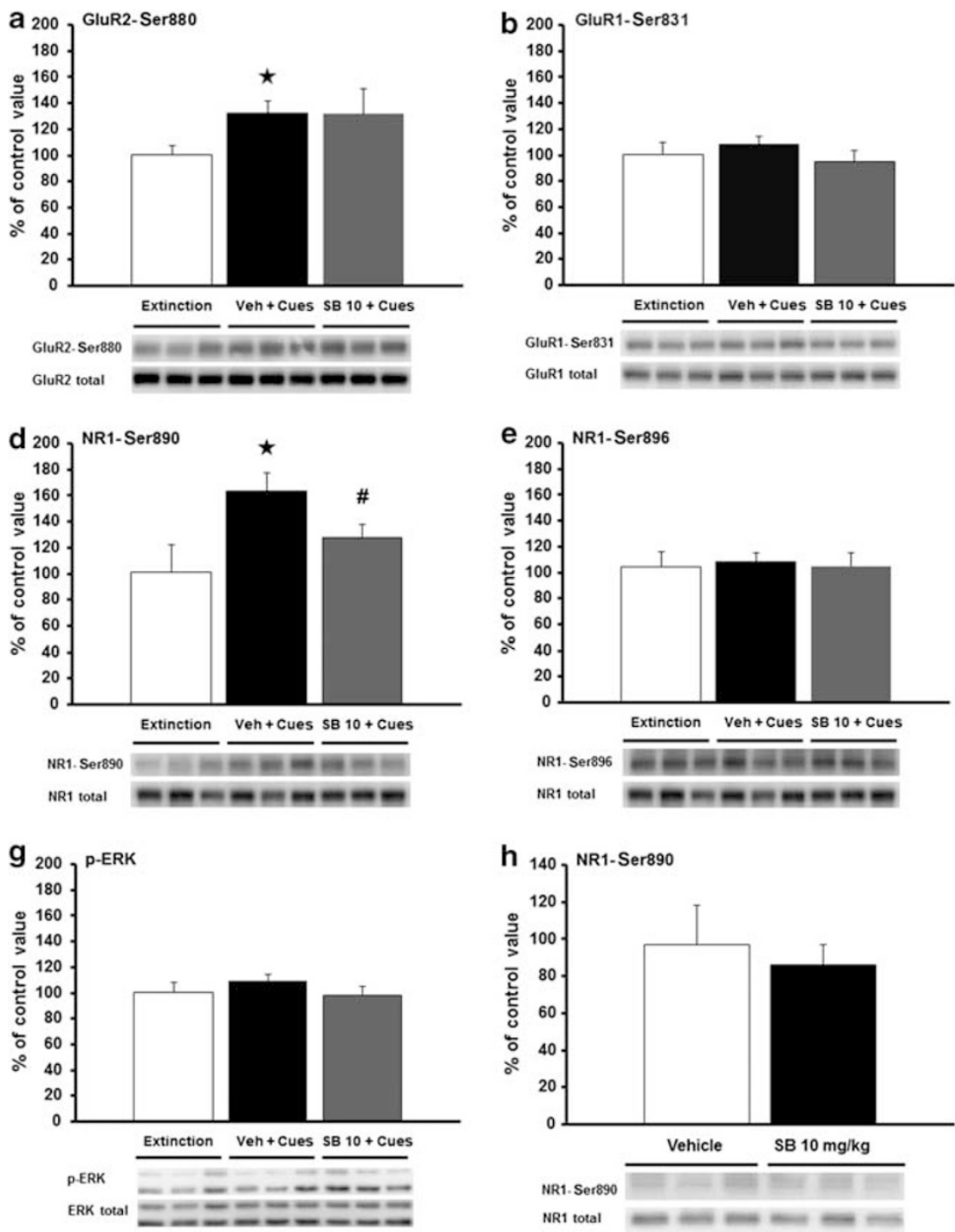
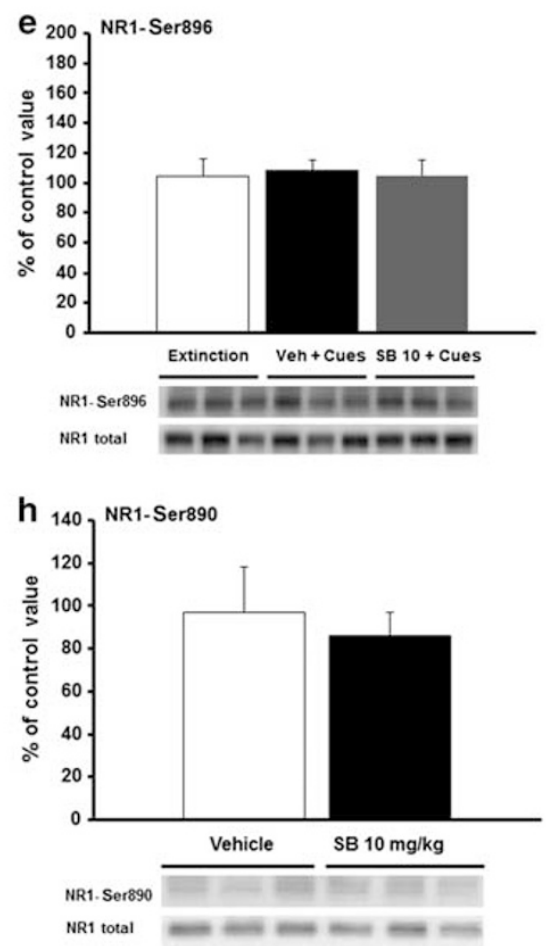
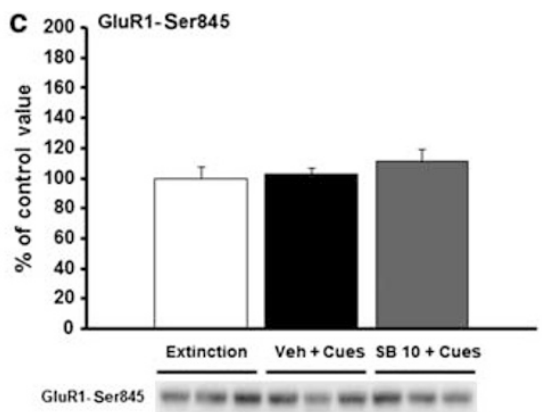

GluR1 total
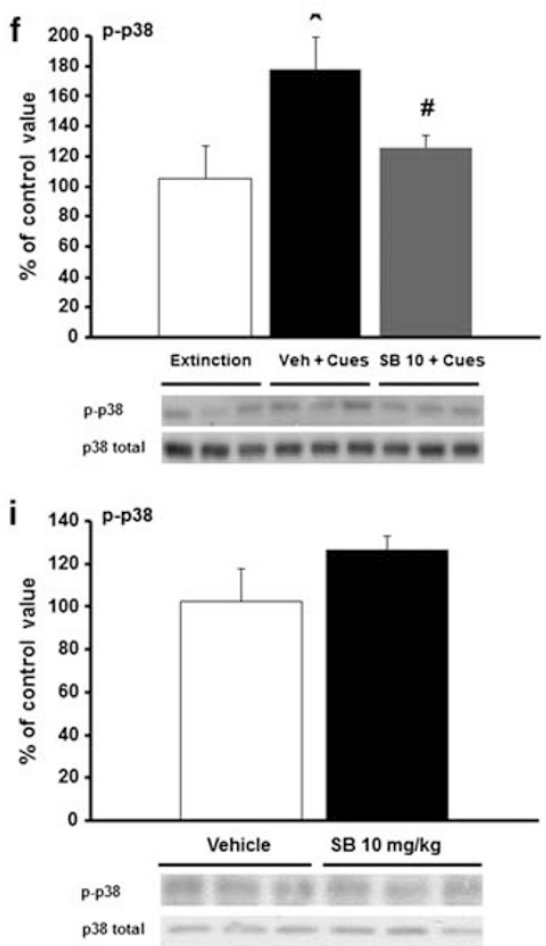

Figure 2 Cue-induced reinstatement of nicotine-seeking increases phosphorylation levels of GluR2-Ser880, NRI-Ser890, and p38 MAPK in the nucleus accumbens (NAc). Hcrtr-I selectively contributes to NRI-Ser890 and p38 MAPK phosphorylations. (a-g) Phosphorylation of (a) GluR2-Ser880, (b) GluRI-Ser83I, (c) GluRI-Ser845, (d) NRI-Ser890, (e) NRI-Ser896, ( $f$ ) p38 MAPK, and (g) ERK in the NAc of mice extinguished from nicotine self-administration behavior or re-exposed to nicotine-associated cues after pretreatment with SB334867 ( $10 \mathrm{mg} / \mathrm{kg}$, ip or vehicle; $n=6 \mathrm{mice}$ per group). (h, i) Phosphorylation of (h) NRI-Ser890 and (i) p38 MAPK in the NAc of C57BL/6J naive mice after pretreatment with SB334867 (I0 mg/kg, ip or vehicle; $n=5$ mice per group). Data are expressed as mean $\pm S E M$. $* P<0.05$ compared with the extinction group; ${ }^{\#} P<0.05$ comparison between pretreatments.

observed in the NAc, a new group of C57BL/6J mice were tested for cue-induced reinstatement of food-seeking behavior. Mice were trained to obtain standard food pellets using the same operant paradigm described for nicotine. Two-way ANOVA with repeated measures showed an interaction between training session and hole $\left(\mathrm{F}_{(9,396)}=139.59, P<0.01\right)$, indicating a progress in foodmaintained operant responses (Figure 5a). All the mice trained to respond for food achieved the acquisition criteria in $6 \pm 0.3$ days. Once the training phase was completed, mice underwent extinction sessions. The criterion for extinction was reached by the complete group of mice in $4 \pm 0.1$ days (Figure $5 \mathrm{~b}$ ). One day after mice extinguished the behavior, they were tested for cue-induced reinstatement of food-seeking behavior. The reinstatement experi- ments were performed using a between-subjects design. Thus, mice were divided into 4 treatment groups: vehicle, SB334867 (5 and $10 \mathrm{mg} / \mathrm{kg}$, ip), and TCSOX229 (10 mg/kg, ip). Two-way ANOVA with repeated measures revealed that the treatment groups tested for reinstatement showed similar levels of responding during the acquisition period. Thus, no interaction was observed between active responding across days and the treatment received on reinstatement $\left(\mathrm{F}_{(27,288)}=0.76\right.$, NS). Mice re-exposed to food-associated cues reinstated the previously extinguished food-seeking behavior (Figure 5c and d). However, in contrast to mice responding for nicotine cues, pretreatment with SB334867 ( 5 and $10 \mathrm{mg} / \mathrm{kg}$, ip) did not induce any effect on cueinduced reinstatement of food-seeking $\left(\mathrm{F}_{(2,21)}=0.74, \mathrm{NS}\right)$ (Figure 5c). Likewise, pretreatment with the Hcrtr-2 


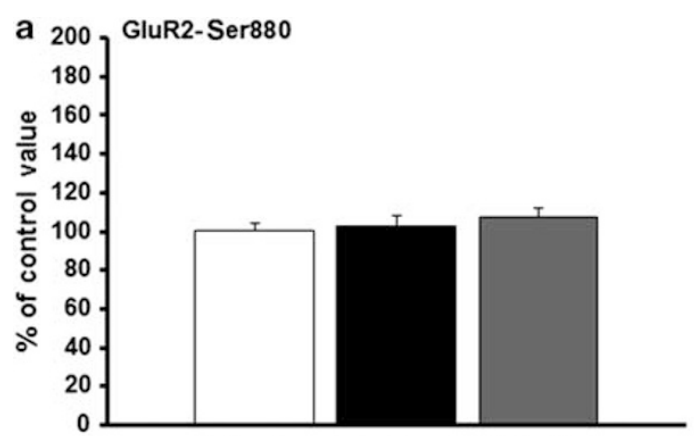

Extinction Veh + Cues SB $10+$ Cues

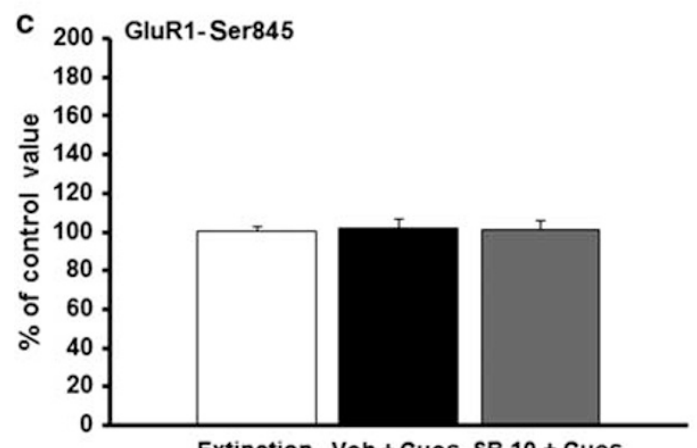

Extinction Veh +Cues SB $10+$ Cues

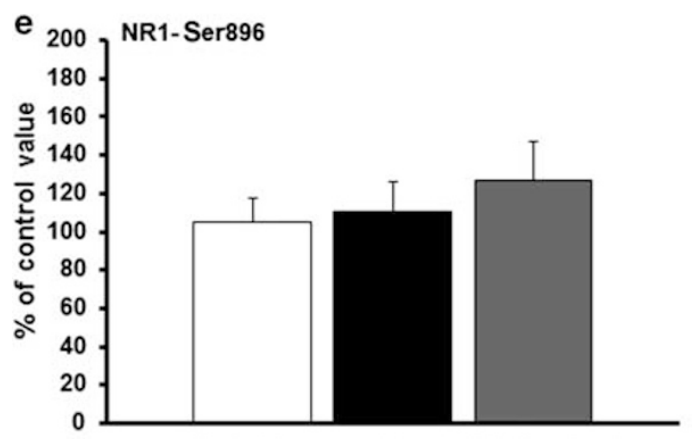

Extinction Veh + Cues SB $10+$ Cues
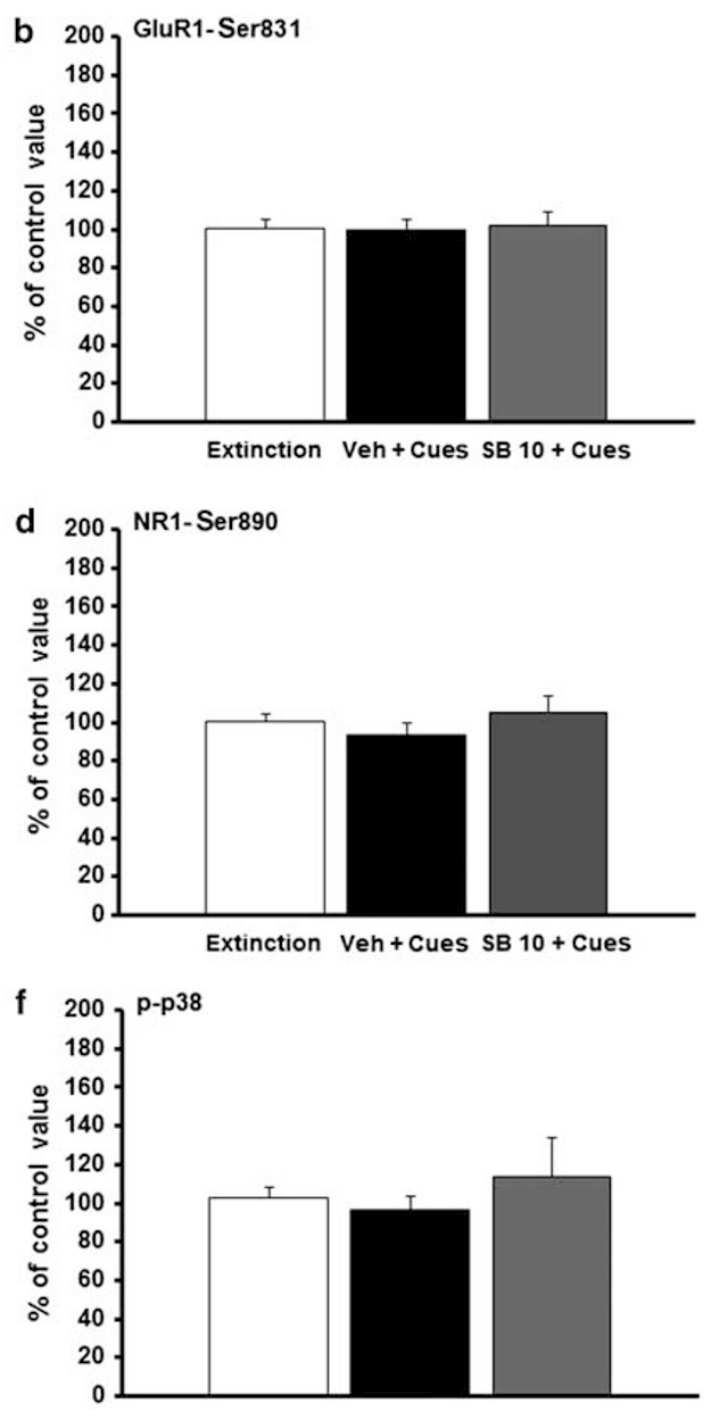

Extinction Veh +Cues SB $10+$ Cues

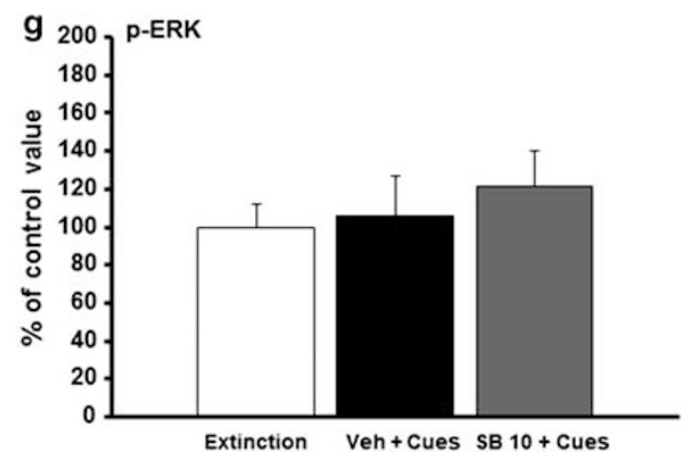

Figure 3 Prefrontal cortex (PFC) phosphorylation levels are not affected by cue-induced reinstatement of nicotine-seeking behavior. (a-g) Phosphorylation levels of (a) GluR2-Ser880, (b) GluRI-Ser83I, (c) GluRI-Ser845, (d) NRI-Ser890, (e) NRI-Ser896, (f) p38 MAPK, and (g) ERK in the PFC of mice extinguished from nicotine self-administration behavior or re-exposed to nicotine-paired cues after pretreatment with SB334867 $(10 \mathrm{mg} / \mathrm{kg}$, ip or vehicle; $n=7$ mice per group). Data are expressed as mean \pm SEM.

antagonist TCSOX229 (10 mg/kg, ip) did not influence reinstatement of nicotine-seeking triggered by foodconditioned cues $\left(\mathrm{F}_{(1,13)}=1.25\right.$, NS) (Figure 5d). These results point toward a differential and specific role for Hcrtr-1 in the modulation of cue-induced nicotine-seeking behavior.
Cue-Induced Reinstatement of Food-Seeking was not Associated with Increased Phosphorylation of GluR2-Ser880, NR1-Ser890 and p38 MAPK in the NAc

The phosphorylation levels of GluR2-Ser880, NR1-Ser890 and p38 MAPK were analyzed in the NAc of mice tested for 
a
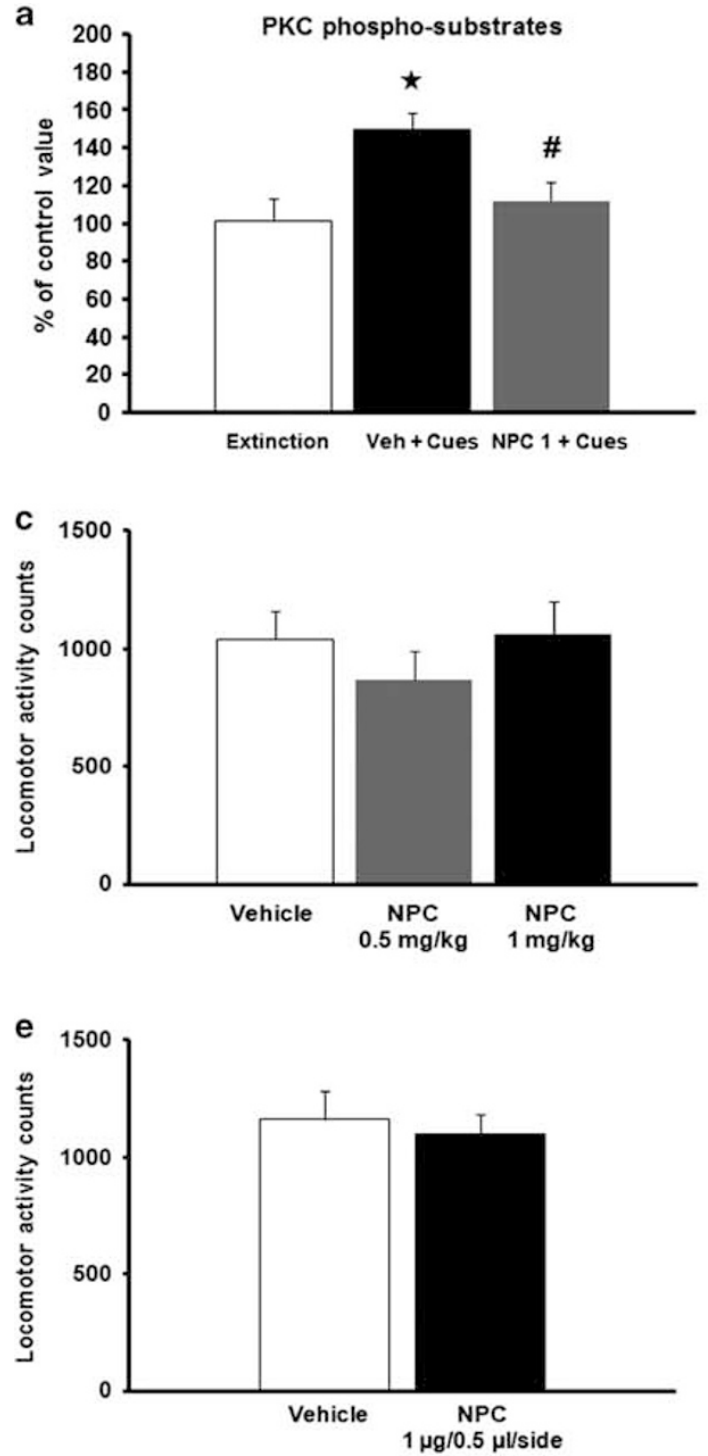
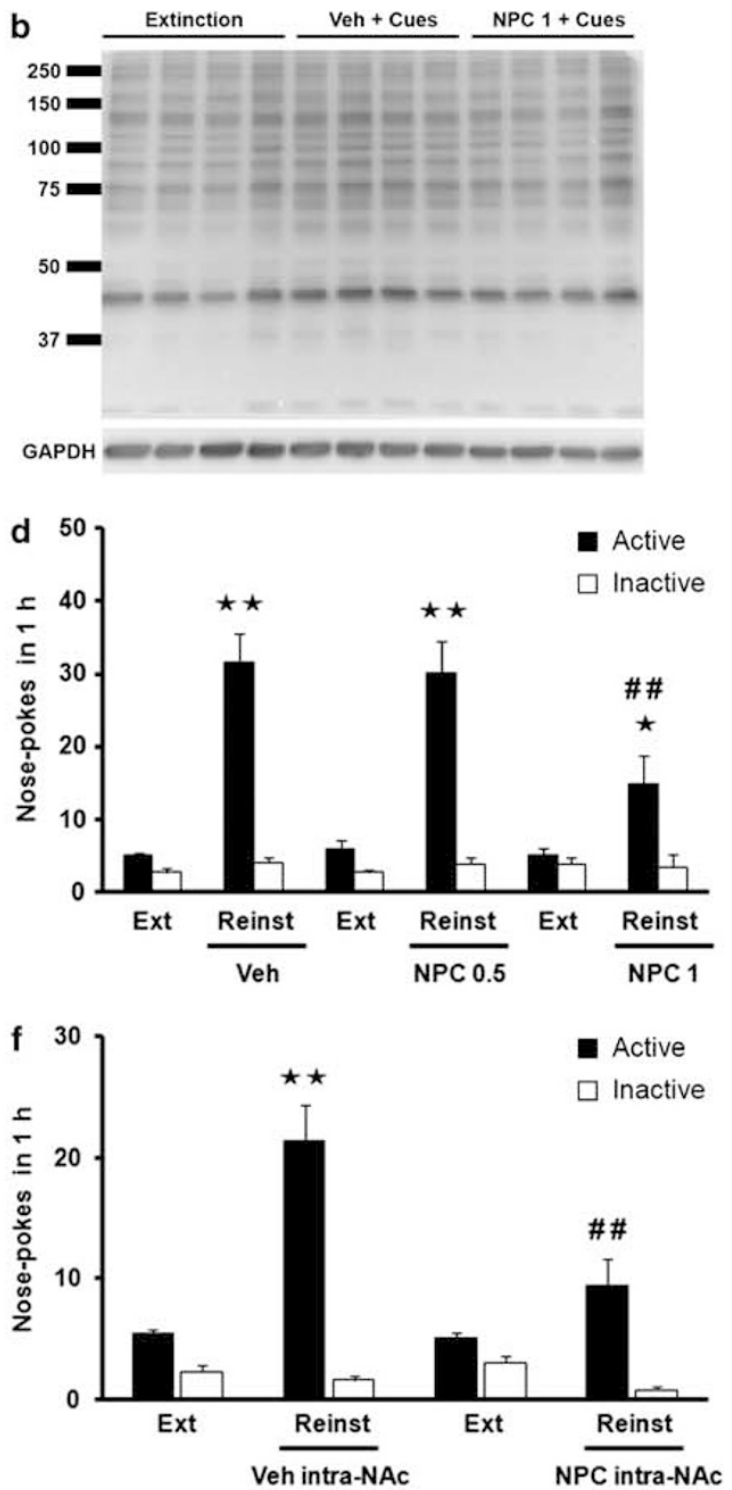
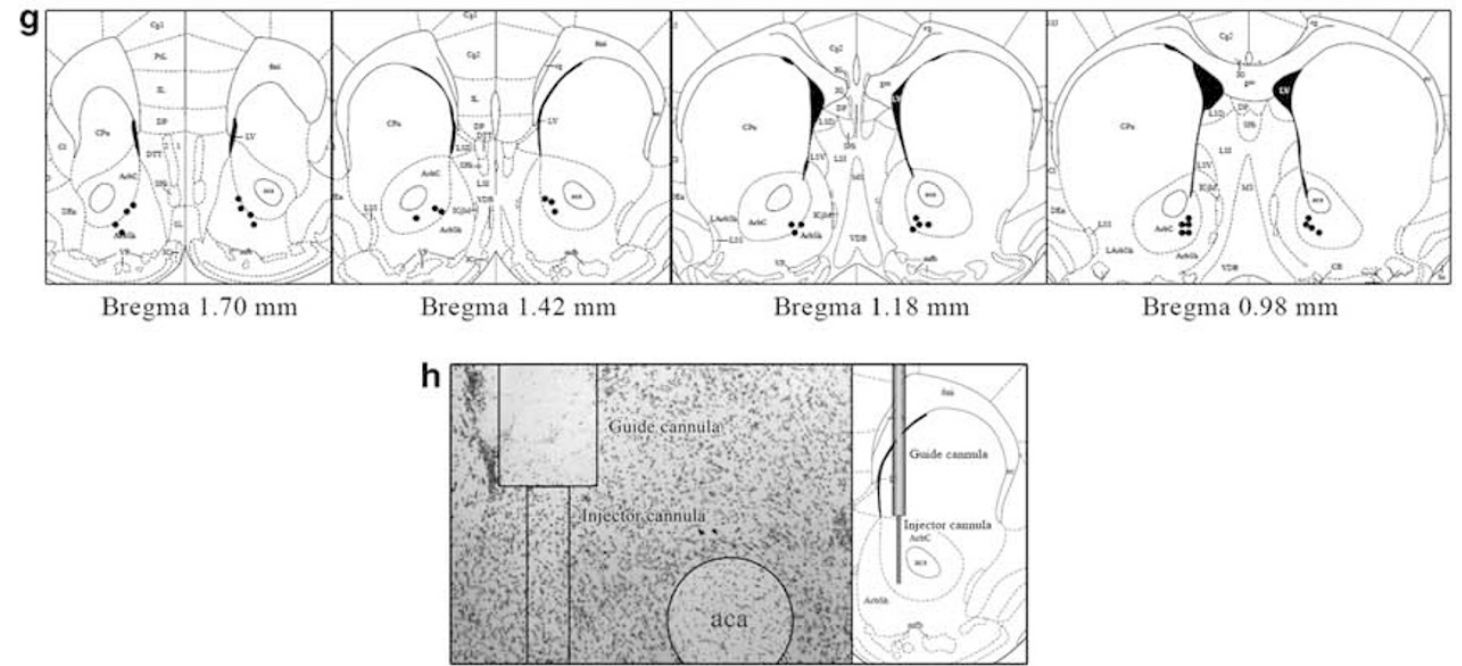

Figure 4 For caption please refer page 1732. 
reinstatement of food-seeking. In contrast to the results obtained for nicotine, cue-induced food-seeking did not induce changes in the phosphorylation levels of GluR2-Ser880, NR1-Ser890, and p38 MAPK in the NAc (Figure 5e-g). Additionally, pretreatment with SB334867 $(10 \mathrm{mg} / \mathrm{kg}$, ip) did not have any effect on the abovementioned phosphorylations in the NAc (Figure 5e-g). These data suggest that different biochemical mechanisms underlie food- and nicotine-seeking behavior after re-exposure to reward-associated cues.

\section{DISCUSSION}

This report demonstrates that blockade of Hcrtr-1, but not Hcrtr-2, attenuates cue-induced reinstatement of nicotineseeking behavior. By contrast, hypocretin transmission does not influence reinstatement of food-seeking elicited by foodpaired cues under our experimental conditions (standard food in food-deprived mice), suggesting a specific role for Hcrtr-1 in the responses promoted by nicotine-associated cues. Reinstatement of nicotine-seeking was associated with specific changes in glutamate transmission and MAPK signaling in the NAc. Thus, PKC-dependent phosphorylation of GluR2-Ser880 and NR1-Ser890 as well as phosphorylation of p38 MAPK were increased in the NAc of mice re-exposed to nicotine-associated cues. Interestingly, phosphorylation of NR1-Ser890 and p38 MAPK selectively depended on Hcrtr-1 activation. Moreover, inhibition of accumbal PKC signaling effectively reduced reinstatement of cue-induced nicotineseeking.

We have recently shown that the intracerebroventricular infusion of hypocretin-1 reinstates a previously extinguished nicotine-seeking behavior in mice by a mechanism independent of the CRF system (Plaza-Zabala et al, 2010). Thus, the $\mathrm{CRF}_{1}$ receptor antagonist antalarmin did not block the effects of hypocretin-1 on reinstatement, whereas the Hcrtr-1 antagonist SB334867 did not modify the CRFdependent footshock stress-induced reinstatement of nicotine-seeking (Plaza-Zabala et al, 2010). In agreement, hypocretins and CRF use independent mechanisms to modulate cocaine-seeking behavior, at least at the level of the ventral tegmental area (VTA) (Wang et al, 2009). In this study, we demonstrate that the blockade of Hcrtr-1 attenuates cue-induced reinstatement of nicotine-seeking in a dose-dependent manner, suggesting that presentation of the cues previously associated with nicotine is sufficient to evoke the release of endogenous hypocretins to drive this behavior. Consistently, hypocretin neurons from the $\mathrm{LH}$ and the PFA showed an increase in c-Fos expression following presentation of nicotine-associated cues. In agreement with our results, Hcrtr-1 signaling has also been reported to modulate cue-induced reinstatement of alcohol (Lawrence et al, 2006), cocaine (Smith et al, 2009), and heroin-seeking behavior (Smith and Aston-Jones, 2012). Moreover, reinstatement of alcohol-seeking behavior elicited by stimuli linked to ethanol availability increased the number of c-Fos-positive hypocretin neurons in the lateral hypothalamic area (Dayas et al, 2008). The existence of a functional dichotomy for hypocretin cell populations has been proposed (Harris and Aston-Jones, 2006), with hypocretin cells located in the LH mainly involved in reward processing while those located in the DMH/PFA having a role in the regulation of arousal and stress. The activation of hypocretin cells observed in the present study could be due to the increase in motivation and attentional processing involved in the relapse to nicotine-seeking elicited by nicotine-paired cues. However, the effect of stress commonly related to hypocretin cells of the DMH would be less important in this process. In agreement with our results, context-induced reinstatement of alcoholseeking behavior increased c-Fos expression in hypocretin cells located in the LH and the PFA but not in the DMH (Hamlin et al, 2007). In any case, further studies will be required to confirm the possible different physiological role of the diverse hypocretin cell populations.

The present results point to a specific role for Hcrtr-1 in relapse to nicotine-seeking as the Hcrtr-2 antagonist TCSOX229 did not modify this response. In agreement, Hcrtr-2 did not participate in cue-induced relapse to cocaine-seeking behavior (Smith et al, 2009). Moreover, both hypocretin receptor antagonists did not prevent cueinduced food-seeking behavior under our experimental conditions (standard food in food-restricted mice). Indeed, hypocretins seem to have a role in food-seeking and taking when motivation is high (palatable and/or salient foods) (Mahler et al, 2012a). Thus, SB334867 reduced cue-induced reinstatement of sucrose seeking in food-restricted rats (Cason and Aston-Jones, 2013). However, consistent with our results, SB334867 did not reduce reinstatement of highfat food-seeking elicited by hypocretin-1, a food prime, or yohimbine (Nair et al, 2008), although food-seeking driven by conditioned cues was not evaluated in this previous study.

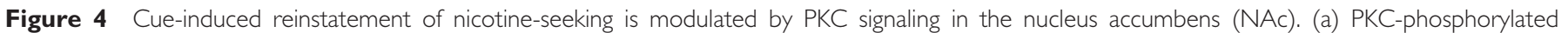

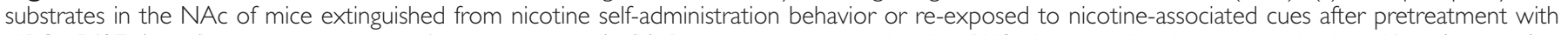

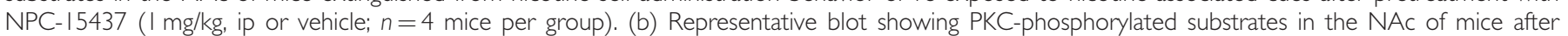

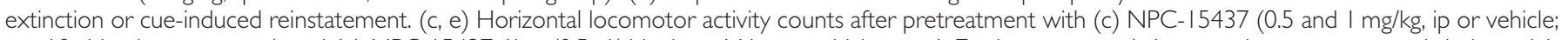

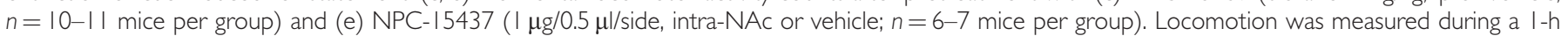

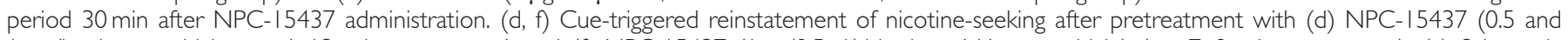

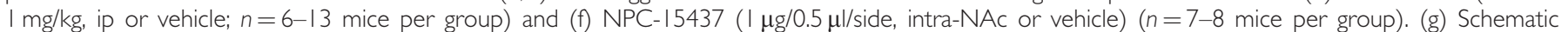

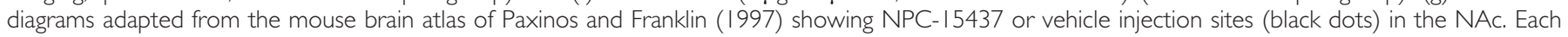

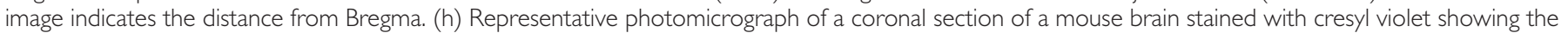

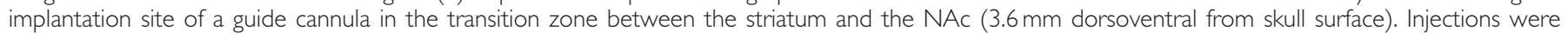

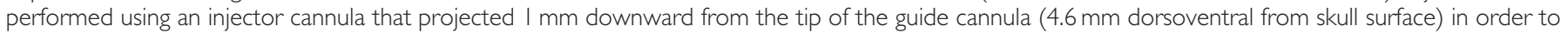
reach the central part of the NAc. The core and shell subregions were not distinguished. Data are expressed as mean \pm SEM. $* P<0.05$, $* * P<0.01$

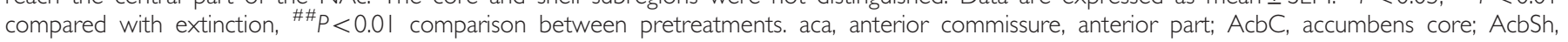
accumbens shell. 

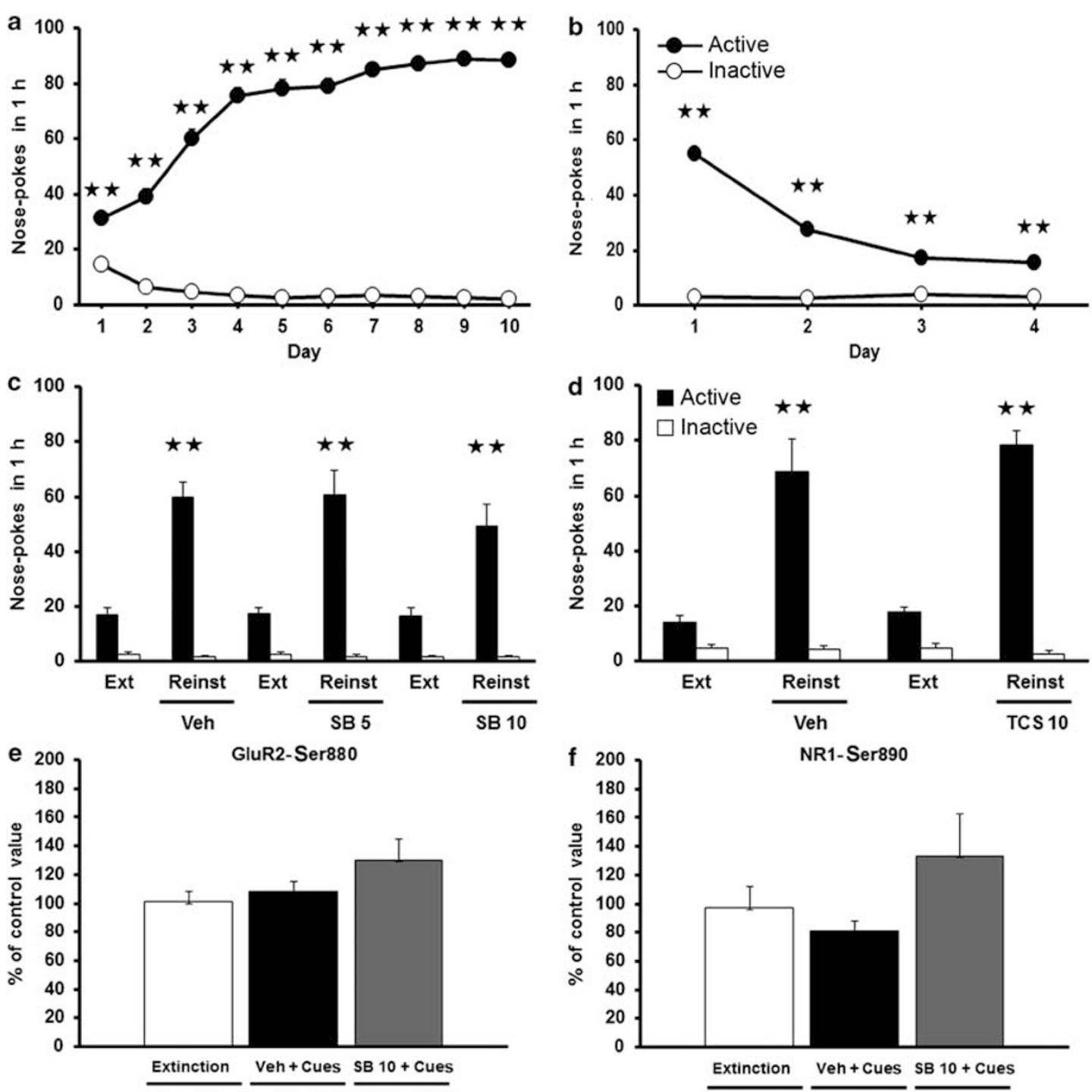

GluR2.Ser880

NR1.Ser890

NR1 total

GluR2 total

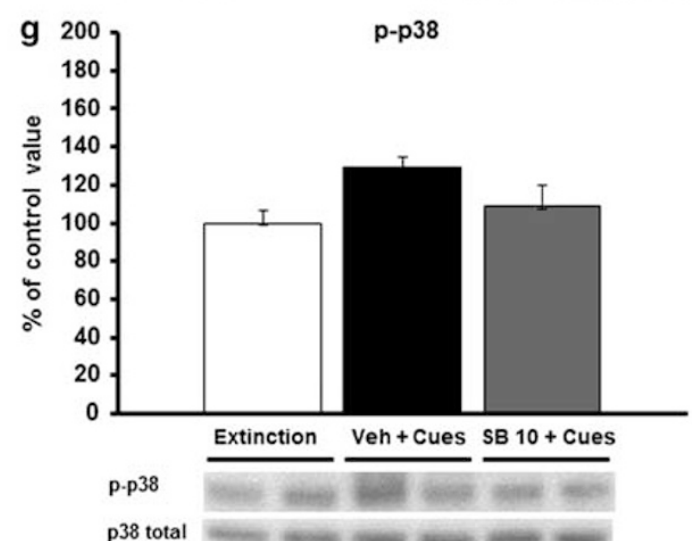

Figure 5 Hypocretin transmission does not influence cue-induced reinstatement of food-seeking behavior. Presentation of food-associated cues does not modify phosphorylation levels of GluR2-Ser880, NRI-Ser890, and p38 MAPK in the nucleus accumbens (NAc). (a-d) Mean number of nose-poking responses in the active (black) and inactive (white) holes during (a) acquisition of food-maintained operant behavior $(n=38)$, (b) extinction $(n=38)$, and (c, d) reinstatement of cue-induced food-seeking behavior after pretreatment with (c) SB334867 (0, 5, and $10 \mathrm{mg} / \mathrm{kg}$, ip $n=7-9 \mathrm{mice}$ per group) or (d) TCSOX229 (0 and $10 \mathrm{mg} / \mathrm{kg} ; n=6-8$ mice per group). (e-g) Phosphorylation of (e) GluR2-Ser880, (f) NRI-Ser890, and (g) p38 MAPK in mice extinguished from operant behavior or re-exposed to food-conditioned cues after pretreatment with SB334867 (I0 mg/ $/ \mathrm{kg}$, ip or vehicle). Data are expressed as mean \pm SEM. $(a, b) * * P<0.01$ comparison between holes, $(c, d) * * P<0.0$ I compared with extinction. 
Vulnerability to relapse in addicted patients can persist after years of abstinence, implying that addiction is caused by long-lasting changes in brain function as a result of repeated drug intake (Kalivas and Volkow, 2005). The glutamatergic projection from the PFC to the NAc has been identified as the final common pathway for initiating drug-seeking behaviors, and a variety of molecular adaptations in this brain circuitry have been correlated with the resumption of drug-seeking behavior induced by different addictive drugs (Kalivas and Volkow, 2011). In agreement, attenuation of glutamatergic transmission inhibits the reinstatement of nicotine-seeking in rodents (Knackstedt and Kalivas, 2009). Consistent with the important role of glutamate in drug relapse, we show that reexposure to nicotine-associated cues modifies glutamatergic transmission in the NAc. Thus, reinstatement of nicotineseeking increased phosphorylation of GluR2-Ser880 and NR1-Ser890 in this brain region but not in the PFC. These changes in accumbal glutamatergic transmission are specific as other phosphorylations, such as NR1-Ser896, GluR1Ser831, and GluR1-Ser845 were not modified in the NAc or the PFC by the presentation of nicotine-conditioned cues. In agreement with our results, cocaine-primed reinstatement increased GluR2-Ser880 phosphorylation in the rat NAc shell (Famous et al, 2008). Both GluR2-Ser880 and NR1-Ser890 phosphorylations depend on PKC activation (Tingley et al, 1997; Chung et al, 2000), a kinase related to glutamate receptor trafficking and plasticity mechanisms (Sanderson and Dell'Acqua, 2011). Upon PKC activation, a rapid dispersal of NMDA receptors from synaptic to extrasynaptic sites has been observed in cultured hippocampal neurons (Fong et al, 2002; Ferreira et al, 2011). Moreover, PKCinduced phosphorylation of Ser890, but not Ser896, disrupts surface-associated NR1 subunit clusters in heterologous cell systems (Tingley et al, 1997), suggesting that PKC stimulation facilitates lateral diffusion of NMDA receptors out of the synapse, where they could be subsequently targeted for internalization (Carroll and Zukin, 2002). Likewise, PKCdependent phosphorylation of GluR2-Ser880 induces rapid internalization of GluR2-containing AMPA receptors in neuronal cultures (Chung et al, 2000). Interestingly, the inhibition of PKC-induced GluR2 subunit internalization in the NAc blocks cocaine-primed reinstatement (Famous et al, 2008), suggesting that PKC might be involved in the reinitiation of drug-seeking behaviors. Here, we show that reinstatement of nicotine-seeking after presentation of nicotine-paired cues increased PKC-phosphorylated substrates in the NAc. Moreover, intra-NAc infusion of the PKC inhibitor NPC-15437 abolished cue-elicited reinstatement of nicotine-seeking, thus confirming a crucial role for PKC signaling within the NAc in relapse to nicotine-seeking triggered by re-exposure to nicotine-conditioned cues. The MAPK pathway is also critical for the regulation of synaptic plasticity (Wang et al, 2007). In agreement, we observed an increase in p38 MAPK phosphorylation levels in the NAc on presentation of nicotine-associated cues, while phosphorylation of ERK remained unchanged. Interestingly, p38 MAPK pathway has an active role in the internalization of AMPA receptors during some forms of long-term depression (Zhu et al, 2002; Zhong et al, 2008), although the participation of this pathway in NMDA receptor trafficking has not been assessed yet. Notably, the changes that we report in accumbal transmission are selectively engaged during the execution of nicotine-seeking behaviors. Thus, phosphorylation levels of GluR2-Ser880, NR1-Ser890, and p38 MAPK were not modified on presentation of food-conditioned cues during reinstatement of food-seeking behavior, suggesting that different biochemical mechanisms underlie food- and nicotine-seeking behaviors following re-exposure to rewardassociated cues. Future studies will be required to elucidate the exact contribution of the biochemical changes observed in the NAc to the reinstatement of nicotine-seeking behavior.

The Hcrtr-1 antagonist SB334867 blocks cocaine-induced long-term potentiation in VTA excitatory synapses (Borgland et al, 2006), indicating that Hcrtr-1 activation modulates glutamatergic synaptic transmission. Consistent with this hypothesis, we have shown that SB334867 selectively attenuates the enhanced phosphorylation levels of NR1Ser890 and p38 MAPK in the NAc of mice re-exposed to nicotine-associated cues. These effects do not seem to be directly modulated by Hcrtr-1 in the NAc as Hcrtr-2 is the main receptor expressed in this brain region (Marcus et al, 2001; Cluderay et al, 2002). Other key areas related to the execution of drug-seeking behaviors, such as the VTA or the PFC, where Hcrtr-1 expression is more abundant (Marcus et al, 2001) could be responsible for this effect. Accordingly, cue-induced reinstatement of cocaine-seeking is dependent upon hypocretin (James et al, 2011) and AMPA receptor interactions within the VTA (Mahler et al, 2012b).

In conclusion, we demonstrate a selective role for Hcrtr-1 in the reinstatement of nicotine-seeking and associated biochemical changes in the NAc promoted by nicotineassociated cues. Moreover, we show that PKC signaling modulates relapse to nicotine-seeking behavior triggered by nicotine-conditioned cues. These results could be of relevance for the design of new therapeutic strategies to achieve smoking cessation.

\section{ACKNOWLEDGEMENTS}

This work was supported by the Instituto de Salud Carlos III grants, no. PI07/0559, no. PI10/00316, and no. RD06/001/001 (RTA-RETICS), by the Spanish Ministry of Science and Technology, Consolider-C no. SAF2007-64062 and no. SAF2011-29864, the Catalan Government (SGR2009-00731), and by the Catalan Institution for Research and Advanced Studies (ICREA Academia program). AP-Z and ÁF are recipients of a predoctoral fellowship from the Spanish Ministry of Education. We thank Cristina Fernández and Marta Linares for invaluable technical assistance.

\section{DISCLOSURE}

The authors declare no conflicts of interest.

\section{REFERENCES}

Aston-Jones G, Smith RJ, Sartor GC, Moorman DE, Massi L, Tahsili-Fahadan P et al (2010). Lateral hypothalamic orexin/ hypocretin neurons: a role in reward-seeking and addiction. Brain Res 1314: 74-90.

Aujla H, Beninger RJ (2003). Intra-accumbens protein kinase C inhibitor NPC 15437 blocks amphetamine-produced conditioned place preference in rats. Behav Brain Res 147: 41-48. 
Benowitz NL (2009). Pharmacology of nicotine: addiction, smoking-induced disease, and therapeutics. Annu Rev Pharmacol Toxicol 49: 57-71.

Berrendero F, Robledo P, Trigo JM, Martín-García E, Maldonado R (2010). Neurobiological mechanisms involved in nicotine dependence and reward: participation of the endogenous opioid system. Neurosci Biobehav Rev 35: 220-231.

Borgland SL, Taha SA, Sarti F, Fields HL, Bonci A (2006). Orexin A in the VTA is critical for the induction of synaptic plasticity and behavioral sensitization to cocaine. Neuron 49: 589-601.

Caggiula AR, Donny EC, White AR, Chaudhri N, Booth S, Gharib MA et al (2001). Cue dependency of nicotine self-administration and smoking. Pharmacol Biochem Behav 70: 515-530.

Carroll RC, Zukin RS (2002). NMDA-receptor trafficking and targeting: implications for synaptic transmission and plasticity. Trends Neurosci 25: 571-577.

Cason AM, Aston-Jones G (2013). Role of orexin/hypocretin in conditioned sucrose-seeking in rats. Psychopharmacology (Berl) 226: 155-165.

Chiamulera C (2005). Cue reactivity in nicotine and tobacco dependence: a 'multiple-action' model of nicotine as a primary reinforcement and as an enhancer of the effects of smokingassociated stimuli. Brain Res Brain Res Rev 48: 74-97.

Chung HJ, Xia J, Scannevin RH, Zhang X, Huganir RL (2000). Phosphorylation of the AMPA receptor subunit GluR2 differentially regulates its interaction with $\mathrm{PDZ}$ domain-containing proteins. J Neurosci 20: 7258-7267.

Cluderay JE, Harrison DC, Hervieu GJ (2002). Protein distribution of the orexin-2 receptor in the rat central nervous system. Regul Pept 104: 131-144.

Dayas CV, McGranahan TM, Martin-Fardon R, Weiss F (2008). Stimuli linked to ethanol availability activate hypothalamic CART and orexin neurons in a reinstatement model of relapse. Biol Psychiatry 63: 152-157.

De Biasi M, Dani JA (2011). Reward, addiction, withdrawal to nicotine. Annu Rev Neurosci 34: 105-130.

Famous KR, Kumaresan V, Sadri-Vakili G, Schmidt HD, Mierke DF, Cha JH et al (2008). Phosphorylation-dependent trafficking of GluR2-containing AMPA receptors in the nucleus accumbens plays a critical role in the reinstatement of cocaine seeking. J Neurosci 28: 11061-11070.

Ferreira JS, Rooyakkers A, She K, Ribeiro L, Carvalho AL, Craig AM (2011). Activity and protein kinase C regulate synaptic accumulation of $\mathrm{N}$-methyl-D-aspartate (NMDA) receptors independently of GluN1 splice variant. J Biol Chem 286: 28331-28342.

Fong DK, Rao A, Crump FT, Craig AM (2002). Rapid synaptic remodeling by protein kinase C: reciprocal translocation of NMDA receptors and calcium/calmodulin-dependent kinase II. J Neurosci 22: 2153-2164.

Gladding CM, Raymond LA (2011). Mechanisms underlying NMDA receptor synaptic/extrasynaptic distribution and function. Mol Cell Neurosci 48: 308-320.

Hamlin AS, Newby J, McNally GP (2007). The neural correlates and role of D1 dopamine receptors in renewal of extinguished alcohol-seeking. Neuroscience 146: 525-536.

Harris GC, Aston-Jones G (2006). Arousal and reward: a dichotomy in orexin function. Trends Neurosci 29: 571-577.

Hollander JA, Lu Q, Cameron MD, Kamenecka TM, Kenny PJ (2008). Insular hypocretin transmission regulates nicotine reward. Proc Natl Acad Sci USA 105: 19480-19485.

James MH, Charnley JL, Levi EM, Jones E, Yeoh JW, Smith DW et al (2011). Orexin-1 receptor signalling within the ventral tegmental area, but not the paraventricular thalamus, is critical to regulating cue-induced reinstatement of cocaine-seeking. Int $\mathrm{J}$ Neuropsychopharmacol 14: 684-690.

Kalivas PW (2009). The glutamate homeostasis hypothesis of addiction. Nat Rev Neurosci 10: 561-572.
Kalivas PW, Volkow ND (2005). The neural basis of addiction: a pathology of motivation and choice. Am J Psychiatry 162: 1403-1413.

Kalivas PW, Volkow ND (2011). New medications for drug addiction hiding in glutamatergic neuroplasticity. Mol Psychiatry 16: 974-986.

Knackstedt LA, Kalivas PW (2009). Glutamate and reinstatement. Curr Opin Pharmacol 9: 59-64.

Lai YT, Fan HY, Cherng CG, Chiang CY, Kao GS, Yu L (2008). Activation of amygdaloid PKC pathway is necessary for conditioned cues-provoked cocaine memory performance. Neurobiol Learn Mem 90: 164-170.

Lawrence AJ, Cowen MS, Yang HJ, Chen F, Oldfield B (2006). The orexin system regulates alcohol-seeking in rats. $\mathrm{Br} J$ Pharmacol 148: $752-759$.

LeSage MG, Perry JL, Kotz CM, Shelley D, Corrigall WA (2010). Nicotine self-administration in the rat: effects of hypocretin antagonists and changes in hypocretin mRNA. Psychopharmacology (Berl) 209: 203-212.

Mahler SV, Smith RJ, Aston-Jones G (2012b). Interactions between VTA orexin and glutamate in cue-induced reinstatement of cocaine seeking in rats. Psychopharmacology (Berl) Mar [Epub ahead of print (doi:10.1007/500213-012-2681-5)].

Mahler SV, Smith RJ, Moorman DE, Sartor GC, Aston-Jones G (2012a). Multiple roles for orexin/hypocretin in addiction. Prog Brain Res 198: 79-121.

Marcus JN, Aschkenasi CJ, Lee CE, Chemelli RM, Saper CB, Yanagisawa $M$ et al (2001). Differential expression of orexin receptors 1 and 2 in the rat brain. J Comp Neurol 435: 6-25.

Martín-García E, Barbano MF, Galeote L, Maldonado R (2009). New operant model of nicotine-seeking behaviour in mice. Int J Neuropsychopharmacol 12: 343-356.

Martín-García E, Burokas A, Kostrzewa E, Gieryk A, Korostynski M, Ziolkowska B et al (2011). New operant model of reinstatement of food-seeking behavior in mice. Psychopharmacology (Berl) 215: 49-70.

Nair SG, Golden SA, Shaham Y (2008). Differential effects of the hypocretin 1 receptor antagonist SB 334867 on high-fat food selfadministration and reinstatement of food seeking in rats. $\mathrm{Br}$ J Pharmacol 154: 406-416.

Paxinos G, Franklin KBJ (1997). The Mouse Brain in Stereotaxic Coordinates. Academic Press: San Diego, CA, USA.

Peyron C, Tighe DK, van den Pol AN, de Lecea L, Heller HC, Sutcliffe JG et al (1998). Neurons containing hypocretin (orexin) project to multiple neuronal systems. J Neurosci 18: 9996-10015.

Plaza-Zabala A, Flores Á, Maldonado R, Berrendero F (2012b). Hypocretin/orexin signaling in the hypothalamic paraventricular nucleus is essential for the expression of nicotine withdrawal. Biol Psychiatry 71: 214-223.

Plaza-Zabala A, Maldonado R, Berrendero F (2012a). The hypocretin/orexin system: implications for drug reward and relapse. Mol Neurobiol 45: 424-439.

Plaza-Zabala A, Martín-García E, de Lecea L, Maldonado R, Berrendero F (2010). Hypocretins regulate the anxiogenic-like effects of nicotine and induce reinstatement of nicotine-seeking behavior. J Neurosci 30: 2300-2310.

Sanderson JL, Dell'Acqua ML (2011). AKAP signaling complexes in regulation of excitatory synaptic plasticity. Neuroscientist 17: 321-336.

Santos SD, Carvalho AL, Caldeira MV, Duarte CB (2009). Regulation of AMPA receptors and synaptic plasticity. Neuroscience 158: 105-125.

Sato T, Tanaka K, Teramoto T, Ohnishi Y, Hirate K, Irifune M et al (2004). Facilitative effect of a novel AVP fragment analog, NC-1900, on memory retention and recall in mice. Peptides 25: 1139-1146.

Smith RJ, See RE, Aston-Jones G (2009). Orexin/hypocretin signaling at the orexin 1 receptor regulates cue-elicited cocaine-seeking. Eur J Neurosci 30: 493-503. 
Smith RJ, Aston-Jones G (2012). Orexin/hypocretin 1 receptor antagonist reduces heroin self-administration and cue-induced heroin seeking. Eur J Neurosci 35: 798-804.

Soria G, Mendizábal V, Touriño C, Robledo P, Ledent C, Parmentier $\mathrm{M}$ et al (2005). Lack of CB1 cannabinoid receptor impairs cocaine self-administration. Neuropsychopharmacology 30: $1670-1680$.

Tingley WG, Ehlers MD, Kameyama K, Doherty C, Ptak JB, Riley CT et al (1997). Characterization of protein kinase A and protein kinase $\mathrm{C}$ phosphorylation of the $\mathrm{N}$-methyl-D-aspartate receptor NR1 subunit using phosphorylation site-specific antibodies. J Biol Chem 272: 5157-5166.

Wang JQ, Fibuch EE, Mao L (2007). Regulation of mitogenactivated protein kinases by glutamate receptors. J Neurochem 100: $1-11$.
Wang JQ, Liu X, Zhang G, Parelkar NK, Arora A, Haines M et al (2006). Phosphorylation of glutamate receptors: a potential mechanism for the regulation of receptor function and psychostimulant action. J Neurosci Res 84: 1621-1629.

Wang B, You ZB, Wise RA (2009). Reinstatement of cocaine seeking by hypocretin (orexin) in the ventral tegmental area: independence from the local corticotropin-releasing factor network. Biol Psychiatry 65: 857-862.

Zhong P, Liu W, Gu Z, Yan Z (2008). Serotonin facilitates longterm depression induction in prefrontal cortex via p38 MAPK/ Rab5-mediated enhancement of AMPA receptor internalization. J Physiol 586: 4465-4479.

Zhu JJ, Qin Y, Zhao M, Van Aelst L, Malinow R (2002). Ras and Rap control AMPA receptor trafficking during synaptic plasticity. Cell 110: 443-455.

Supplementary Information accompanies the paper on the Neuropsychopharmacology website (http://www.nature.com/npp) 